\title{
Diversity and Characterization of Endophytic Bacteria Associated with Tidal Flat Plants and their Antagonistic Effects on Oomycetous Plant Pathogens
}

\author{
Fehmida Bibi, Muhammad Yasir, Geun Cheol Song, Sang Yeol Lee and Young Ryun Chung* \\ Division of Applied Life Science (BK 21), Plant Molecular Biology and Biotechnology Research Center, Gyeongsang National \\ University, Jinju 660-701, Korea
}

(Received on June 30, 2011; Revised on January 9, 2012; Accepted on January 10, 2012)

Endophytic bacterial communities of tidal flat plants antagonistic to oomycete plant pathogens were studied by the isolation of 256 root colonizing endophytic bacteria from surface-disinfected root tissues of six plants (Rosa rugosa, Suaeda maritima, Vitex rotundifolia, Carex scabrifolia, Glehnia littoralis and Elymus mollis) growing in a tidal flat area of Namhae Island, Korea. To understand the antagonistic potential, an in vitro antagonistic assay was performed to characterize and identify strains that were antagonistic to the oomycete plant pathogens Phytophthora capsici and Pythium ultimum from the total population. Nine percent of the total number of isolated bacteria exhibited in vitro inhibitory activity against target plant pathogenic oomycetes. Taxonomic and phylogenetic placement of the antagonistic bacteria was investigated by analysis of the $16 \mathrm{~S}$ rRNA gene sequences. The sequence analysis classified the antagonistic strains into four major classes of the domain bacteria (Firmicutes, $\alpha$-Proteobacteria, $\gamma$-Proteobacteria and Actinomycetes) and 10 different genera. Further production of secondary metabolites, hydrolytic enzymes and plant growth promoting traits were determined for the putative new species of antagonistic endophytic bacteria. These new strains could not be identified as known species of $\alpha$-Proteobacteria, and so may represent novel bacterial taxa. The unexpected high antagonistic bacterial diversity associated with the tidal flat plants may be indicative of their importance in tidal flat plants as a promising source of novel antimicrobial compounds and biocontrol agents.

Keywords : antagonistic endophytes, Phytophthora, plant growth promoting traits, Pythium, tidal flat plants

Bacteria are common inhabitants of both the surfaces and the internal tissues of most plants, and may have diverse effects on the development and physiology of the host plant. Many bacteria on the root surface and in the rhizo-

\footnotetext{
*Corresponding author.

Phone) +82-55-751-5945, FAX) +82-55-759-0187

E-mail)yrchung@gnu.ac.kr
}

sphere benefit plants. In particular, some bacteria residing in the interior of plant tissues and intercellular spaces provide benefits to the host, which include plant growth promotion and induction of plant defense mechanisms, by providing growth-stimulating or resistance-inducing substances or producing antibiotics for outcompeting fungal pathogens (Berg and Hallmann, 2006; Brooks et al., 1994; Chert et al., 1995; Chung et al., 2010; Chung et al., 2008; Ryu et al., 2003), without causing harm (Schulz and Boyle, 2006). The bacteria benefit by being protected from the competitive and high-stress environment of the soil compared to bacteria restricted to the rhizosphere and the rhizoplane (Rosenblueth and Martínez-Romero, 2006). A significant portion of the indigenous endophytic bacteria in plant roots have antagonistic potential toward fungal pathogens. Some Gram-negative species of endophytes such as Pseudomonas, Phyllobacterium, Sphingomonas, Burkholderia and Serratia are able to control different plant pathogens. Gram-positive endophytes commonly found in the genus Bacillus have been isolated from different tissue types in numerous plant species, and have been used for biological control of plant diseases based on the plant bacterial interaction (Berg and Hallmann, 2006). Similarly, Gram-positive endophytic Actinomycetes such as Streptomyces, Microbispora and Nocardioides give excellent control of plant pathogens, Rhizoctonia solani and Pythium spp. (Coombs et al., 2004).

In order to understand the interaction between host plants and their endophytic bacteria, it is useful to know the bacterial diversity associated with the plants. To this end, a number of characterization studies on the structures and functions of bacterial communities of terrestrial plants have been performed (Araujo et al., 2002; Berg and Hallmann, 2006; Coombs and Franco, 2003; Hallmann and Berg, 2006). However, compared with the terrestrial environment, there have been few studies on the endophytic bacteria from the marine environment, despite the demonstrations that many of the marine microorganisms appear to be associated with some particular host and produce novel compounds having unique structures and bioactivities (Dalton et al., 2004; Sgroy et al., 2009; Shin et al., 2007). Many bioactive 
compounds previously found in marine plants and animals may actually be produced or metabolized by associated endophytic microorganisms (Davidson et al., 2001; Jensen and Fenical, 2000; Nathan et al., 2004). The studies on epiphytic and endophytic bacterial communities of marine plants are meager; only a few investigations have been conducted to study the antifungal activities of bacteria isolated from the marine environment. The microbial diversity of this environment remains largely uncharacterized (Jung et al., 2002; Lemos et al., 1985).

In adverse environments, such as drought or high moisture, plants are prone to attack and invasion by a certain group of pathogens and disease defenses may be induced by endophytic bacteria normally associated with the plant under such conditions (Strobel, 2003). Some of the plant pathogens that prefer aquatic environments include oomycetes such as Phytophthora and Pythium, which cause devastating diseases in plants all over the world. Free water or the presence of high humidity is an important condition necessary for the development and pathogenicity of oomycetes (Agrios, 2005). The basic rationale for a search of endophytic bacteria that is antagonistic to oomycetes from tidal flat plants is that, because these plants have successfully evolutionarily differentiated and adapted to saline and moist environments, this tolerance and, at least in part, their successful adaptation could depend on the presence of certain epiphytic or endophytic bacteria. In addition, in a habitat with a certain level of salt and limited nutrients, halophytes such as tidal flat and coastal dune plants harbor a variety of bacteria with considerable diversity (Dalton et al., 2004; Sgroy et al., 2009; Shin et al., 2007). Despite the important role played by bacterial diversity in tidal flat plant communities, little is known about the distribution and mechanism of antagonistic endophytic bacteria associated with tidal flat plants. It is conceivable that the endophytic bacteria of tidal flat plants may be a good source of novel biocontrol agents for oomycete pathogens.

The present study was undertaken to investigate endophytic bacterial communities using a culture-based method from six tidal flat plants growing in the tidal flat on Namhae Island, Korea, screen the endophytic bacteria on the basis of their in vitro antagonistic activity against Phytophthora and Pythium species, identify and characterize antagonistic bacteria and further evaluate plant growth promoting traits of new species of bacteria related to new genera.

\section{Materials and Methods}

Isolation of bacteria from tidal flat plants. Six plant species were collected from the tidal flat of Namhae Island (N 34 ${ }^{\circ} 50^{\prime} 15.62^{\prime \prime}$; E 127 53'32.72") located at the middle of southern part in Korea (Table 1). For the isolation of endophytic bacteria from plant roots, some modifications were made in a previously described isolation process (Chung et al., 2008). Root pieces were washed several times with running tap water and surface sterilized by stepwise washing in $70 \%$ ethanol for $5 \mathrm{~min}, 1.0 \% \mathrm{NaOCl}$ for $10 \mathrm{~min}, 70 \%$ ethanol for about $10 \mathrm{sec}$ and, finally, washed with sterile distilled water several times. To confirm the success of disinfection, washed root segments were placed on R2A agar (Difco Laboratories, Detroit, MI) to allow growth of bacteria after incubation at $28^{\circ} \mathrm{C}$ for 5-6 days. If no microbial growth occurred on the medium surface, sterilization was considered complete. After the confirmation of the surface sterility of root segments, $1.0 \mathrm{~g}$ of the surface sterilized and dried plant root segments were ground in 9.0 $\mathrm{ml}$ of autoclaved filtered sea water (AFS) with a sterile mortar and pestle. Aliquots $(0.1 \mathrm{ml})$ were 10 -fold serially

Table 1. Distribution of endophytic and antagonistic endophytic bacteria isolated from tidal flat plants

\begin{tabular}{|c|c|c|c|c|}
\hline Plant species ${ }^{\mathrm{a}}$ & $\begin{array}{l}\text { Number of } \\
\text { isolates }^{\mathrm{b}}\end{array}$ & $\begin{array}{l}\text { Number of } \\
\text { antagonists }\end{array}$ & Antagonists $(\%)^{\mathrm{d}}$ & Dominant phylum \\
\hline Rosa rugosa & 52 & 5 & 1.9 & $\gamma$-Proteobacteria \\
\hline Vitex rotundifolia & 42 & 4 & 1.6 & NA \\
\hline Suaeda maritima & 48 & 6 & 2.3 & Firmicutes \\
\hline Carex scabrifolia & 44 & 2 & 0.8 & Actinomycetes \\
\hline Glehnia littoralis & 38 & 4 & 1.6 & NA \\
\hline Elymus mollis & 32 & 2 & 0.8 & Firmicutes \\
\hline Total & 256 & 23 & 9.0 & \\
\hline
\end{tabular}

${ }^{a}$ Scientific name of host plant species collected from tidal flat area for the isolation of endophytic bacteria.

${ }^{b}$ Total number of endophytic bacteria isolated from the coastal dune plants.

${ }^{\circ}$ Total number of antagonistic endophytic bacteria against Phytophthora capsici and Pythium ultimum by confrontation bioassay. Activity was determined $4-6$ days at $28^{\circ} \mathrm{C}$ after placing bacterial suspension onto paper disc.

${ }^{\mathrm{d}}$ Percentage of antagonistic endophytic bacteria from total endophytes.

eDominant phylum in all endophytic antagonistic bacteria to oomycetes.

NA, not applicable due to the lack of dominance by a single group. 
diluted $\left(10^{-3}, 10^{-4}\right.$ and $\left.10^{-5}\right)$ in sterile AFS and plated in triplicate on one-tenth strength R2A (1/10 R2A) medium in filtered seawater (FS). To reduce fungal contamination, 50 $\mu \mathrm{g} / \mathrm{ml}$ cycloheximide was added to the medium before plating at $55^{\circ} \mathrm{C}$. The plates were incubated at $28^{\circ} \mathrm{C}$ for $2-3$ weeks and colonies were selected for the pure culture and bioassay on the basis of distinct colony morphology. The strains were isolated, subcultured using 1/10 R2A medium in FS and stored at $-70^{\circ} \mathrm{C}$ in $1 / 10 \mathrm{R} 2 \mathrm{~A}$ broth in FS containing $15 \%(\mathrm{v} / \mathrm{v})$ glycerol for further use.

DNA extraction and 16S rRNA gene analysis of bacteria. The 23 selected endophytic strains among 256 isolates were subjected to extraction of genomic DNA for 16S rRNA gene analysis for identification of strains. Genomic DNA was extracted using commercial genomic DNA extraction kit (Intron Biotech, Seoul, Korea). An approximately $1500 \mathrm{bp}$ fragment of the 16S rRNA gene was amplified from the extracted DNA using bacterial universal primers 27F (5'-AGAGTTTGATCCTGGCTCAG-3') and 1492R (5'-GGTTACCTTGTTACGACTT-3'). Amplifications were performed with the following thermal cycle: one cycle of 94 ${ }^{\circ} \mathrm{C}$ for $5 \mathrm{~min}$ followed by 30 cycles of $94^{\circ} \mathrm{C}$ for $1 \mathrm{~min}$, an annealing of $58^{\circ} \mathrm{C}$ for $50 \mathrm{~s}$ and extension at $72^{\circ} \mathrm{C}$ for $1 \mathrm{~min}$, with a final extension step at $72^{\circ} \mathrm{C}$ for $10 \mathrm{~min}$. The PCR products were separated by agarose gel electrophoresis and purified using PCR purification kit (Intron Biotech) according to the manufacturer's instructions and were sequenced by GenoTech (Daejeon, Korea). To ascertain the phylogenetic position and related type strains of the antagonistic bacteria, the 16S rRNA gene sequence of all isolates were compared with sequences obtained from National Center for Biotechnology Information (NCBI) and using the EzTaxon server (http://www.eztaxon.org/). The closest type species match was recorded along with the percent sequence similarity (Table 2). Sequences were checked for chimera formation with the CHECK_CHIMERA software of the Ribosomal Database Project (Maidak et al., 1996). Multiple alignments of the sequences were performed using CLUSTAL_X version 1.83 (Thompson et al., 1997). Gaps were edited using BioEdit software version 4.7.3 (http:// www.mbio.ncsu.edu/bioedit/bioedit.html). The phylogenetic tree based on 16S rRNA gene sequences was inferred by using the neighbour-joining method with the Jukes and Cantor model in a MEGA4 Program with bootstrap values based on 1000 replications (Tamura et al., 2007).

Analysis of antagonistic activity against oomycete plant pathogens. Antagonistic activity of endophytic bacteria was determined by inhibition of the growth of oomycete pathogens using a confrontation bioassay. The plant pathogenic oomycetes Phytophthora capsici (isolated from pepper, Capsicum annuum) and Pythium ultimum (isolated from cucumber, Cucumis sativus) were obtained in this laboratory and maintained on V8 juice agar $(100 \mathrm{ml} \mathrm{V8}$ juice, $17.0 \mathrm{~g}$ agar and $1.0 \mathrm{~g} \mathrm{CaCO}_{3}$ per liter distilled water, $\mathrm{pH} 6$ ) and potato dextrose agar (PDA; Difco Laboratories), respectively. All isolated endophytic bacteria were screened for their ability to inhibit mycelial growth on modified PDA and V8 media [(half-strength (1/2) PDA and V8 juice agar supplemented with half-strength (1/2) R2A $(0.25 \mathrm{~g}$ yeast extract, $0.25 \mathrm{~g}$ proteose peptone No. 3 (Difco), $0.25 \mathrm{~g}$ casamino acid, $0.25 \mathrm{~g}$ dextrose, $0.25 \mathrm{~g}$ soluble starch, $0.15 \mathrm{~g}$ sodium pyruvate, $\left.\left.0.15 \mathrm{~g} \mathrm{~K}_{2} \mathrm{HPO}_{4}, 0.03 \mathrm{~g} \mathrm{MgSO}_{4}\right)\right]$ in $11 \mathrm{FS}$ by using an established paper disc method. Endophytic bacteria were grown in $1 / 2 \mathrm{R} 2 \mathrm{~A}$ broth supplemented with $0.5 \%(\mathrm{w} / \mathrm{v})$ soybean meal flour in FS for $48 \mathrm{~h}$ at $28^{\circ} \mathrm{C}$ on a rotary shaker $(120 \mathrm{rpm})$. Paper discs were placed at equidistant places $(1 \mathrm{~cm}$ from the edge $)$ in the plates and impregnated with $100 \mu \mathrm{l}$ aliquots of culture suspension. Each $6 \mathrm{~mm}$ mycelial disc of 4-day-old oomycete pathogens grown on PDA (Py. ultimum) and V8 juice agar (P. capsici) was then placed in the center of the plate and incubated at $28^{\circ} \mathrm{C}$ for 4-6 days. All strains were tested in two independent replicates against oomycete pathogens. The antagonistic activity was estimated by measuring the inhibition zone of mycelial growth of the pathogens around the bacterial colony.

Production of cell wall hydrolyzing enzymes. Production of enzymes reported to be related with the hydrolysis of fungal cell wall was measured to understand the possible antagonistic mechanism of isolated endophytic bacteria. Cellulase activity was determined as described previously and cellulase positive bacteria were detected by the formation of a yellow halo against a red background (Hendricks et al., 1995). Chitinase activity was tested as described previously (Singh et al., 1999) with some modification by using $1 / 2$ R2A agar medium containing $0.5 \%$ $(\mathrm{w} / \mathrm{v})$ colloidal chitin. The presence of a clear zone around the colony was detected after 7 days incubation at $28^{\circ} \mathrm{C}$. Protease activity was checked by using $0.5 \%(\mathrm{w} / \mathrm{v})$ skim milk in $1 / 2 \mathrm{R} 2 \mathrm{~A}$ agar media and the activity was determined by checking for the formation of a clear zone around the colony after 5 days incubation at $28^{\circ} \mathrm{C}$. Secretion of $\beta$ 1,3-glucanase was tested by streaking bacterial strains on $1 / 2$ R2A agar media containing pachyman $(0.2 \%, \mathrm{w} / \mathrm{v})$ and aniline blue $(0.005 \%, \mathrm{w} / \mathrm{v})$, on which the positive bacteria formed a clear halo around the colony (Hong and Meng, 2003).

Characterization of plant growth promotion traits and in vitro plant growth promotion assay. Mineral solubilization and other plant growth promoting traits were deter- 
mined for putative new antagonistic endophytic bacteria related to new genera. Phosphate solubilization activity was assayed using medium containing inorganic tricalcium phosphate with some modifications (15 g agar, $10 \mathrm{~g}$ glucose, $5 \mathrm{~g} \mathrm{NH}_{4} \mathrm{Cl}, 1 \mathrm{~g} \mathrm{NaCl}, 1 \mathrm{~g} \mathrm{MgSO}{ }_{4} \cdot 7 \mathrm{H}_{2} \mathrm{O}, 0.8 \mathrm{~g} \mathrm{Ca}_{3}\left(\mathrm{HPO}_{4}\right)_{2}$, $0.5 \mathrm{~g}$ yeast extract, $\mathrm{pH}$ 7.2) for the evaluation of phosphate solubilizing bacteria (Nautiyal, 1999). Bacterial strains were stabbed in triplicate and incubated at $28^{\circ} \mathrm{C}$ for $10-12$ days; uninoculated medium with tricalcium phosphate source served as control. Solubilization of mineral phosphate is characterized by the formation of a clear halo around bacterial colonies with phosphate solubilization capacity. The O-CAS assay was used to detect siderophore produced by antagonistic endophytic bacteria (Perez-Miranda et al., 2007). Pure bacteria were stabbed on CAS agar plates and incubated at $28^{\circ} \mathrm{C}$ for $2-3$ days. Siderophore detection was determined after $10 \mathrm{ml}$ overlays of CAS medium without nutrient was applied over agar containing cultivated siderophore-producing bacteria. After a maximum period of 30$50 \mathrm{~min}$, a change in color of positive bacteria was observed in the overlay medium. Gordon and Weber's colorimetric assay (Gordon and Weber, 1951) was used to measure indole-3-acetic acid (IAA) production in vitro by bacteria. Bacteria were grown in $2 \%$ tryptic soy broth (TSB) with shaking (130 rpm) for $48 \mathrm{~h}$ in the dark at $28^{\circ} \mathrm{C}$. From this bacterial culture, $5 \%(\mathrm{v} / \mathrm{v})$ of inoculum was transferred into $5 \mathrm{ml}$ of the same medium amended with tryptophan (200 $\mu \mathrm{M})$ at $30^{\circ} \mathrm{C}$ in the dark with shaking for $72 \mathrm{~h}$. Endophytic strains were pelleted by centrifugation $(9,000 \mathrm{~g})$ for $10 \mathrm{~min}$ at $4{ }^{\circ} \mathrm{C}$, and $1 \mathrm{ml}$ of Salkowsky's reagent $(2 \mathrm{ml}$ of $0.5 \mathrm{M}$ $\mathrm{FeCl}_{3}$ with $49 \mathrm{ml}$ of $35 \%$ [v/v] $\mathrm{HClO}_{4}$ ) was added to the supernatant $(1 \mathrm{ml})$ and incubated for $30 \mathrm{~min}$ at room temperature. The IAA present in the culture supernatant reacted with the reagent to yield a pink-colored product.

To determine the ability to reduce nitrate, two antagonistic bacteria YC 6887 and YC 6898 strains were tested using nitrate reduction medium (Smibert and Krieg, 1994). The ability to promote plant growth was analyzed by using Arabidopsis thaliana (Col-0) seeds. Seeds of $A$. thaliana ecotype Columbia (Col-0) were surface sterilized by $70 \%$ ethanol ( $1 \mathrm{~min})$ and $1 \% \mathrm{NaOCl}(3 \mathrm{~min})$, and then washed several times with sterilized distilled water. The seeds were placed at $4{ }^{\circ} \mathrm{C}$ for 2 days as dormant releasing, sown on Petri dishes containing MS medium and placed in a growth chamber at $21^{\circ} \mathrm{C}$ with an alternation $12 \mathrm{~h}$ photoperiod of light and dark. Plant growth promotion was determined as described previously (Domenech et al., 2007). Both strains were grown in marine broth (Difco) overnight at $30^{\circ} \mathrm{C}$. After centrifugation for $10 \mathrm{~min}$ at $9,000 \mathrm{~g}$, the bacterial cells were re-suspended in $10 \mathrm{mM} \mathrm{MgSO}_{4}$ solution and the concentration was adjusted to $10^{8}$ colony forming units (cfu)/ml (which corresponded to an optical density at 595 nm of 0.3). Two-week-old seedlings of Arabidopsis were transplanted to pots containing autoclaved soil. Prior to transfer of the seedlings, a $100 \mathrm{ml}$ suspension of the bacterial strain was mixed with $1 \mathrm{~kg}$ of soil and 2-week-old seedlings were transferred to the bacteria containing soil. Control soil was supplemented with an equal volume of 10 $\mathrm{mM} \mathrm{MgSO}_{4}$ solution. Two weeks after inoculation, the second application of bacterial strains with same dose as the first one was applied to seedling roots by a soil drench to achieve the same bacterial density $\left(10^{7} \mathrm{cfu} / \mathrm{g}\right.$ soil $)$. Controls were supplied with the same volume of $10 \mathrm{mM} \mathrm{MgSO}_{4}$ buffer. Twenty plants were used in each treatment with three replicates. All these experiments for plant growth promotion traits were tested twice.

Nucleotide sequence numbers. The nucleotide sequences determined for 23 strains in this study have been deposited in the GenBank database under accession numbers HM800924 to HM800946. The 16S rRNA gene sequences of related type strains were obtained from GenBank database at the NCBI website (http://www.ncbi.nlm.nih.gov).

\section{Results}

Isolation of antagonistic endophytic bacteria. A total of 256 endophytic bacteria forming morphologically different colonies were isolated from roots of six different tidal flat plants: Rosa rugosa, Suaeda maritima, Vitex rotundifolia, Carex scabrifolia, Glehnia littoralis and Elymus mollis (Table 1). All the isolated strains were cultured on 1/10 R2A (medium) in FS. Some of the resulting bacterial colonies were so small that 2-3 weeks of growth was required to render them visible. These endophytic bacteria were screened for their ability to suppress mycelial growth of the oomycetes Py. ultimum and P. capsici in an in vitro bioassay. Of the 256 endophytic bacteria examined, 23 $(9.0 \%)$ displayed inhibitory activity to the two oomycete plant pathogens. Activity of these endophytic antagonists against $P y$. ultimum was stronger as compared to $P$. capsici. In terms of the host plant, the proportion of antagonistic endophytic bacteria varied in different samples, being highest in Suaeda maritima $(\mathrm{n}=6 ; 2.3 \%)$ followed by Rosa rugosa $(\mathrm{n}=5 ; 1.9 \%)$, Glehnia littoralis $(\mathrm{n}=4 ; 1.6 \%)$, Vitex rotundifolia $(\mathrm{n}=4 ; 1.6 \%)$, Elymus mollis $(\mathrm{n}=2 ; 0.8 \%)$ and Carex scabrifolia $(\mathrm{n}=2 ; 0.8 \%)$ (Table 1). The frequency of the different groups of antagonistic bacteria varied in the different plant species, where Firmicutes was the dominant phylum (Table 1). Among the 23 antagonistic bacteria, Bacillus species were dominant followed by species of Pseudomonas, Stenotrophomonas, Staphylococcus and Microbacterium. The strong antagonistic activity with 6-7 mm mycelial inhibition of oomycetes was observed for endo- 
Table 2. Taxonomic classification, antagonistic and cell wall degrading enzymes production of antagonistic endophytic bacteria from tidal flat plants

\begin{tabular}{|c|c|c|c|c|c|c|c|c|}
\hline \multirow{2}{*}{$\begin{array}{l}\text { Origin/ } \\
\text { Strains } \\
\text { number }\end{array}$} & \multirow{2}{*}{ Closely related type strain } & \multirow{2}{*}{$\begin{array}{c}\%^{\mathrm{a}} \\
\text { identity }\end{array}$} & \multicolumn{2}{|c|}{$\begin{array}{l}\text { Antagonistic } \\
\text { activity against }^{\mathrm{b}}\end{array}$} & \multicolumn{4}{|c|}{ Enzyme production $^{\mathrm{c}}$} \\
\hline & & & $\begin{array}{c}P y . \\
\text { ultimum }\end{array}$ & $\begin{array}{c}P . \\
\text { capsici }\end{array}$ & Cellulase & Chitinase & Protease & $\begin{array}{c}\beta-1,3 \\
\text { glucanase }\end{array}$ \\
\hline \multicolumn{9}{|c|}{ Rosa rugosa } \\
\hline YC6887 & Martelella mediterranea MACL11 ${ }^{\mathrm{T}}$ & 98.3 & +++ & ++ & ++ & - & - & + \\
\hline YC6888 & Pseudomonas koreensis Ps 9-14 ${ }^{\mathrm{T}}$ & 99.1 & + & + & - & - & - & + \\
\hline YC6889 & Bacillus gibsonii DSM $8722^{\mathrm{T}}$ & 99.5 & + & + & + & - & + & - \\
\hline YC6890 & Pseudomonas brenneri CFML 97-391 ${ }^{\mathrm{T}}$ & 99.4 & ++ & ++ & - & + & - & - \\
\hline YC6891 & Stenotrophomonas rhizophila e-p10 ${ }^{\mathrm{T}}$ & 98.8 & ++ & ++ & + & - & - & + \\
\hline \multicolumn{9}{|c|}{ Vitex rotundifolia } \\
\hline YC6892 & Bacillus stratosphericus $41 \mathrm{KF} 2 \mathrm{a}^{\mathrm{T}}$ & 100 & ++ & ++ & - & - & - & + \\
\hline YC6893 & Staphylococcus saprophyticus GTC $843^{\mathrm{T}}$ & 98.2 & + & + & + & - & - & - \\
\hline YC6894 & Staphylococcus epidermidis ATCC $14990^{\mathrm{T}}$ & 99.8 & ++ & + & + & + & + & - \\
\hline YC6895 & Micrococcus endophyticus YIM 56238 ${ }^{\mathrm{T}}$ & 99.2 & ++ & + & - & + & ++ & - \\
\hline YC6896 & Microbacterium arborescens DSM $20754^{\mathrm{T}}$ & 100 & ++ & + & - & + & + & + \\
\hline YC6897 & Stenotrophomonas maltophilia ATCC $13637^{\mathrm{T}}$ & 98.8 & +++ & + & +++ & - & + & - \\
\hline \multicolumn{9}{|c|}{ Suaeda maritima } \\
\hline YC6898 & Hoeflea alexandrii $\mathrm{AM} 1 \mathrm{~V} 30^{\mathrm{T}}$ & 95.9 & ++ & + & + & - & - & + \\
\hline YC6900 & Paenibacillus barcinonensis BP- $23^{\mathrm{T}}$ & 98.8 & + & + & - & - & - & + \\
\hline YC6901 & Microbacterium laevaniformans IFO $15234^{\mathrm{T}}$ & 99.6 & + & + & - & + & - & + \\
\hline YC6902 & Mycobacterium frederiksbergense DSM $44346^{\mathrm{T}}$ & 99.2 & + & + & + & - & - & + \\
\hline \multicolumn{9}{|c|}{ Carex scabrifolia } \\
\hline YC6904 & Bacillus safensis FO-036 $\mathrm{b}^{\mathrm{T}}$ & 100 & ++ & ++ & - & - & + & + \\
\hline YC6905 & Bacillus aerius $24 \mathrm{~K}^{\mathrm{T}}$ & 100 & + & + & + & - & - & - \\
\hline \multicolumn{9}{|c|}{ Glehnia littoralis } \\
\hline YC6906 & Bacillus gibsonii DSM $8722^{\mathrm{T}}$ & 99.7 & ++ & + & ++ & - & - & - \\
\hline YC6907 & Bacillus thioparans BMP-1 ${ }^{\mathrm{T}}$ & 99.8 & + & + & - & - & - & + \\
\hline YC6908 & Pseudomonas koreensis Ps 9-14 ${ }^{\mathrm{T}}$ & 99.3 & + & + & + & - & - & - \\
\hline YC6909 & Stenotrophomonas maltophilia ATCC $13637^{\mathrm{T}}$ & 99.1 & + & + & + & - & - & - \\
\hline \multicolumn{9}{|c|}{ Elymus mollis } \\
\hline YC6910 & Bacillus stratosphericus $41 \mathrm{KF} 2 \mathrm{a}^{\mathrm{T}}$ & 100 & ++ & + & - & ++ & - & - \\
\hline YC6911 & Bacillus pumilus DSM $27^{\mathrm{T}}$ & 99.8 & + & + & - & - & ++ & - \\
\hline
\end{tabular}

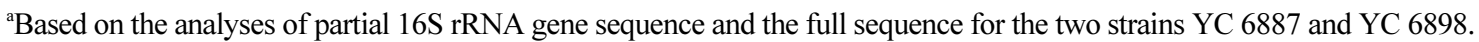

${ }^{b}$ The antagonistic activity was determined by in vitro confrontation bioassay using a paper disc method. The activity was estimated after $4-6$ days incubation at $28^{\circ} \mathrm{C}$ by measuring the clear zone of mycelial growth inhibition:,$+<3 \mathrm{~mm}$; ++, between 4 to $5 \mathrm{~mm}$; +++, between 6 to $7 \mathrm{~mm}$.

${ }^{\mathrm{c}}$ Production of cellulase, chitinase, protease and $\beta-1,3$ glucanase was determined by plate assay. Rating of enzymatic activity was determined as zone of halo formed around bacterial colonies: -, Negative; +, $<3 \mathrm{~mm}$; ++, between 4 to $5 \mathrm{~mm}$; ++, between 6 and $7 \mathrm{~mm}$.

phytic bacteria YC6887 and YC6897, which displayed the closest sequence similarity to Martelella mediterranea MACL11 ${ }^{\mathrm{T}}$ and Stenotrophomonas maltophilia ATCC $13637^{\mathrm{T}}$, respectively (Table 2 ).

Table 2 summarizes the effect of each isolate upon the growth of pathogens tested. The antagonistic endophytes YC6890, YC6891, YC6892 and YC6904 had moderate inhibition activity (4-5 mm, ++) against both target pathogens. Strains YC6888, YC6889, YC6893, YC6900, YC6901, YC6902, YC6905, YC6907, YC6909 and YC6911 showed weak activity $(<3 \mathrm{~mm},+)$. Isolates YC6894, YC6895,
YC6896, YC6897, YC6898, YC6906 and YC6910 strongly inhibited one pathogen and weakly inhibited the other.

Phylogenetic analysis of endophytic bacteria on the basis of 16S rRNA gene sequence. The 23 endophytic bacteria that were antagonistic to oomycetes isolated from the halophytes were identified by partial 16S rRNA gene sequence analysis. Ten different genera were identified and where in turn assigned to four major classes: Firmicutes $(\mathrm{n}=11 ; 47.8 \%), \alpha$-Proteobacteria $(\mathrm{n}=2 ; 8.7 \%), \gamma$-Proteobacteria $(\mathrm{n}=6 ; 26.1 \%)$ and Actinobacteria $(\mathrm{n}=4 ; 17.4 \%)$ 


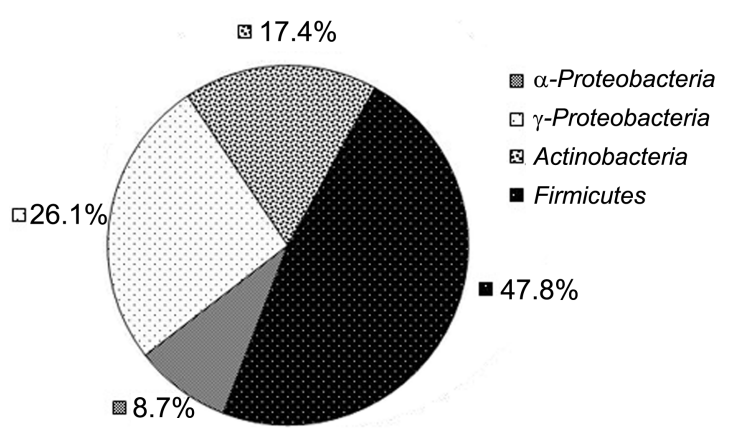

Fig. 1. Percentage composition of different phyla of antagonistic endophytes from total population of antagonistic endophytic bacteria on the basis of 16S rRNA gene sequence similarity.
(Fig. 1). A phylogenetic tree was generated from the distance data using the neighbor-joining method with the Jukes and Cantor model in a MEGA4 Program (Fig. 2). For the 16S rRNA gene data, branching patterns remained consistent, depending on which sequences of other related type strains of different genera and distantly related sequences were included in the data set. The correspondingly high bootstrap values resulted in significant branching points in the 16S rRNA gene sequence based phylogenetic tree.

Sequence identity within $95.9 \%-100 \%$ and their phylogenetic relationships to representative type strains of genera are shown in Fig. 2. Strains representative of class Firmicutes were placed in the cluster recovered with

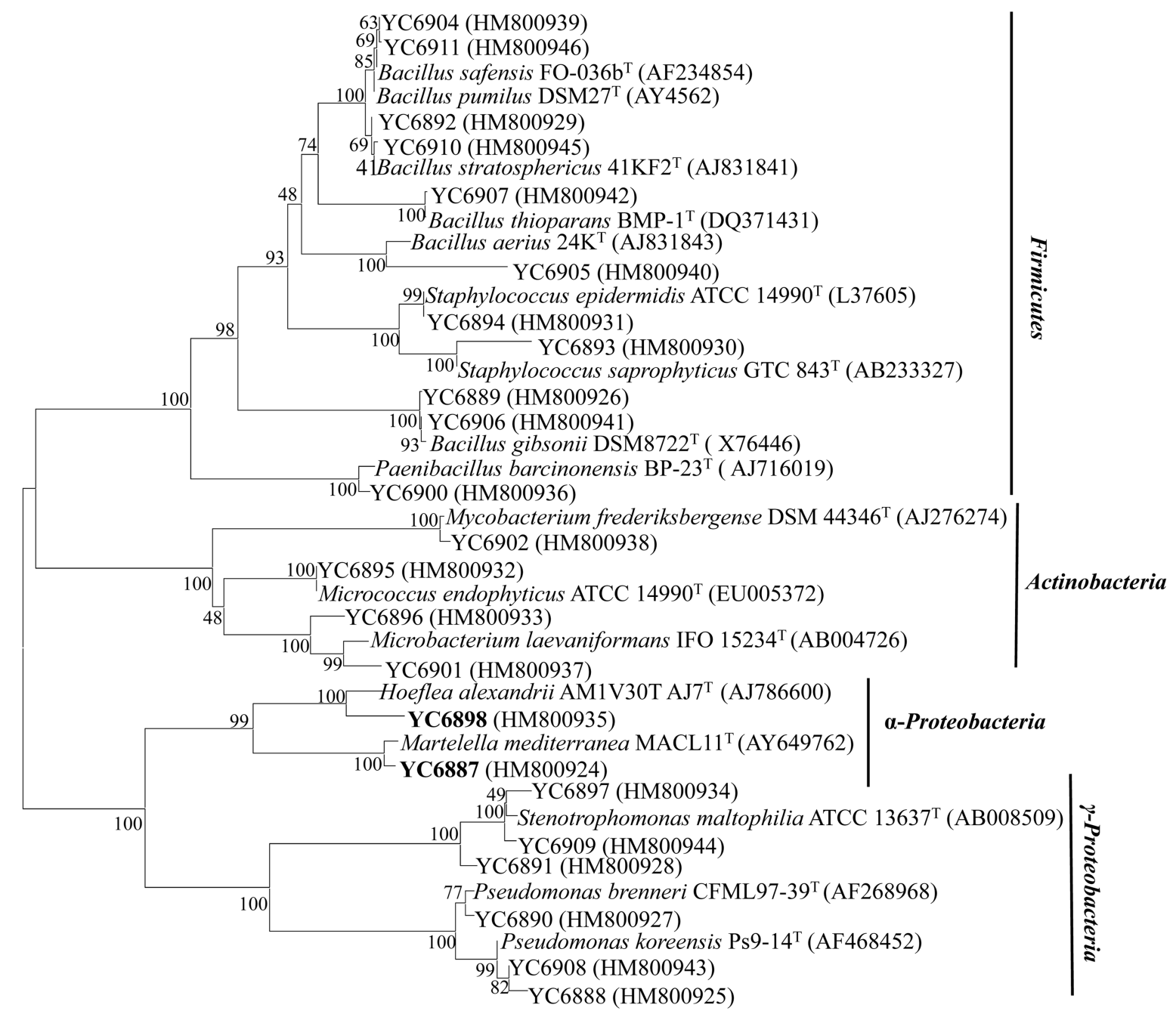

$\stackrel{\vdash}{0.01}$

Fig. 2. Phylogenetic placement of endophytic bacteria isolated from roots of tidal flat plants on the basis of 16S rRNA gene sequences obtained from endophytic bacteria and closely related sequences of the type strains representative of other species of genera. The phylogenetic relationships among taxa were inferred from the $16 \mathrm{~S}$ rRNA gene by using the neighbor-joining method from distances computed with the Jukes-Cantor algorithm. Bootstrap values of $>60 \%$ (1,000 replicates) are shown next to the branches. GenBank accession numbers for each sequence are shown in parentheses. Bar, 0.01 accumulated changes per nucleotide. 
bootstrap values higher than 47\%. Strains YC6892 and YC6910 were almost identical to each other. In addition, YC6889 and YC6906 were identical to each other with high bootstrap value (100\%). These isolates mainly belonged to the genera Bacillus, Staphylococcus and Paenibacillus. Representative of class Actinobacteria were placed in three clusters of different genera, where one isolate (YC6895) was identical to an endophyte, Micrococcus endophyticus YIM56238 ${ }^{\mathrm{T}}$. The $\alpha$-Proteobacteria strains were placed in two different genera in the phylogenetic tree with $100 \%$ of the bootstrap analyses (Fig. 1). From the phylogenetic tree, the representative strains of $\gamma$-Proteobacteria were identified as species of Stenotrophomonas and Pseudomonas. Both strains, YC6897 and YC6909 distinctly clustered with the species Stenotrophomonas maltophilia with bootstrap value of 49\%-100\%. The strains YC6888, YC6890, YC6891 and YC6908 were clearly identified as Pseudomonas strains by the formation of a well-defined cluster (77-100\% bootstrap value) with $P$. brenneri and $P$. koreensis. In addition to antagonistic endophytes from common genera (Table 1), some endophytes with a low 16S rRNA gene sequence similarity $(<98 \%)$ were also recovered. The antagonistic strains with low partial $16 \mathrm{~S}$ rRNA gene sequence similar to the newly defined genera were selected and the full sequences were analyzed. Based on this full sequence analysis, two of the identified strains were confirmed to not belong to validly published species, indicative of their putative identity as new species with similarities of $<98.4 \%$ to the closest type strains in GenBank (Table 2). From these new antagonistic endophytes, strain YC6887 and YC6898 with a sequence similarity of $98.3 \%$ and $95.9 \%$, respectively, to the closest known relative type strain belonged to class $\alpha$-Proteobacteria. The highest BLAST hit search for these two strains YC6887 and YC6898 was to unclassified Martelella mediterranea MACL11 ${ }^{\mathrm{T}}$ and Hoeflea alexandrii AM1V30 ${ }^{\mathrm{T}}$, respectively. These two strains formed a phylogenetically distinct cluster with the type strain of the respective genera (Fig. 2). Detailed characterizations of other isolates are currently being done in comparison with the nearest type strains to determine whether they are new species. Taxonomic description of these putative novel species will be further characterized elsewhere.

The dominant classes of antagonistic strains were Firmicutes (47.8\%) and $\gamma$-Proteobacteria (26.1\%), where Bacillus and Pseudomonas were the dominant genera, and revealed their broad distribution among the coastal dune plants (Fig. 1). The diversity of antagonistic endophytic bacteria was plant species dependent as different taxa with antagonistic activity were exclusively isolated from a single host plant (Table 2). The Gram positive antagonistic endophyte Firmicutes was comprised of the genera Bacillus $(\mathrm{n}=8 ; 34.8 \%)$, Staphylococcus $(\mathrm{n}=2 ; 8.7 \%)$ and Paenibacillus $(\mathrm{n}=1 ; 4.3 \%)$. The bacteria exhibited $99.5 \%-100 \%$ $16 \mathrm{~S}$ rRNA gene sequence similarity with the type strain of related species. Actinomycetes $(n=4 ; 17.4 \%)$ accounted for a different proportion of total antagonistic endophytes from all six coastal dune plants. Members of the Actinomycetes with the sequence similarity of $99.2 \%-100 \%$ were mainly Microbacterium ( $\mathrm{n}=2 ; 8.7 \%)$, Micrococcus $(\mathrm{n}=1 ; 4.3 \%)$ and Mycobacterium spp. (n=1;4.3\%). These species were isolated from only two host plants, S. maritima and $V$. rotundifolia. The Gram negative antagonistic endophytes from class Proteobacteria were grouped in $\alpha$-Proteobacteria and $\gamma$-Proteobacteria subdivisions. The $\alpha$-Proteobacteria

Table 3. Growth promotion traits and in vitro plant growth promotion assay of endophytic strains recovered from roots of tidal flat plants

\begin{tabular}{|c|c|c|c|c|c|c|}
\hline \multirow{2}{*}{$\begin{array}{c}\text { Strain } \\
\text { number }\end{array}$} & \multirow{2}{*}{$\begin{array}{l}\text { Closely related } \\
\text { type strain }\end{array}$} & \multicolumn{4}{|c|}{ Growth promotion characteristics ${ }^{\mathrm{a}}$} & \multirow[b]{2}{*}{$\begin{array}{l}\text { Growth }^{\mathrm{f}} \\
\text { promotion }\end{array}$} \\
\hline & & $\begin{array}{c}\text { Phosphate } \\
\text { solubilization }^{\mathrm{b}}\end{array}$ & $\begin{array}{c}\text { IAA } \\
\text { production }^{\mathrm{c}}\end{array}$ & $\begin{array}{l}\text { Siderophore } \\
\text { producction }^{\mathrm{d}}\end{array}$ & $\begin{array}{l}\text { Nitrate }^{\mathrm{e}} \\
\text { reduction }\end{array}$ & \\
\hline YC 6887 & Martelella mediterranea & ++ & + & - & + & + \\
\hline YC 6898 & Hoeflea alexandrii & + & + & + & - & - \\
\hline
\end{tabular}

${ }^{a}$ Growth promotion characteristics were determined by checking mineral solubilization, IAA production, siderophore production, nitrate reduction and in vitro plant growth promotion assay.

${ }^{\text {b} P h o s p h a t e ~ s o l u b i l i z a t i o n ~ w a s ~ d e t e r m i n e d ~ u s i n g ~ T r i c a l c i u m ~ p h o s p h a t e ~(T C P) ~ a s ~ s u b s t r a t e ~(N a t h a n ~ e t ~ a l ., ~ 2004): ~+, ~ h y d r o l y s i s ~ w i t h ~ z o n e ~ o f ~} 2-3$ $\mathrm{mm} ;++$, hydrolysis of TCP with clear zone of $4-5 \mathrm{~mm}$.

'Indole-3-acetic acid (IAA) production was measured using Gordon and Weber's colorimetric assay (Gordon and Weber, 1951): +; weak positive. ${ }^{\mathrm{d}}$ Siderophore production was determined using O-CAS assay (Perez-Miranda et al., 2007): -, negative; +; positive.

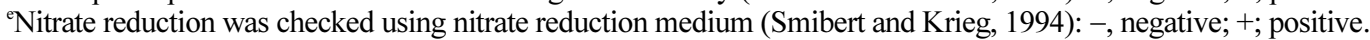

In vitro plant growth promotion effect of two strains was determined using Arabidopsis thaliana Col 0 (Domenech et al., 2007). 100 ml suspension $\left(10^{8} \mathrm{cfu} / \mathrm{ml}\right)$ of strain YC6887 or YC6898 was mixed with $1 \mathrm{~kg}$ of soil prior to transfer of the two weeks old seedlings of Arabidopsis. A second dose of bacterial strain was applied to seedling roots by a soil drench, to achieve the same bacterial density ( $10^{7} \mathrm{cfu} / \mathrm{g}$ soil) $2 \mathrm{weeks}$ after the first inoculation. Control soil was supplemented with an equal volume of $10 \mathrm{mM} \mathrm{MgSO}_{4}$ solution. Twenty plants were used in each treatment with three replicates. All these experiments for plant growth promotion traits were tested twice.

Growth promotion was observed two weeks after the second inoculation of strain YC6887 and YC6898: -, no effect on plant growth; +, promotion of plant growth. 
(16S rRNA gene sequence similarity 98.3\%-95.9\%) comprised a small proportion of antagonistic endophytes $(n=2$; $8.7 \%$ ). The second subdivision, $\gamma$-Protobacteria, was comprised of six different antagonistic endophytes with the $16 \mathrm{~S}$ rRNA gene sequence similarity of $98.8 \%-99.4 \%$. The antagonistic endophytes belonging to subdivision $\gamma$-Proteobacteria comprised two genera: Pseudomonas $(\mathrm{n}=3 ; 13.0 \%)$ and Stenotrophomonas $(\mathrm{n}=3 ; 13.0 \%)$ (Table 2). Antagonistic endophytes of these six coastal dune plants mainly belonged to Firmicutes and $\gamma$-Proteobacteria (Fig. 1).

Production of cell wall hydrolyzing enzymes by antagonistic endophytic bacteria. All 23 antagonistic endophytic bacteria were further characterized for their in vitro production of fungal cell wall hydrolyzing enzymes such as cellulase, chitinase, protease and $\beta-1,3$ glucanase (Table 2). The proportion of the antagonistic endophytic bacteria with cellulase activity $(n=12 ; 52.2 \%)$ was higher as compared to other enzymatic activities. Most of antagonistic endophytes belonged to the phylum Firmicutes such as YC6889, YC6893, YC6894, YC6902, YC6905 and YC6906 had stronger comparative cellulase activity. The endophytic strain YC6897, which displayed strong antagonistic activity against Py. ultimum, had the strongest comparative cellulase activity. Chitinase production was observed in different bacteria at a lower proportion than cellulolytic bacteria $(n=6 ; 26.1 \%)$. The Actinomycetes strains YC6895, YC6896 and YC6901 had chitinolytic activity. Proteolytic activity was detected only in the Gram positive endophytic bacteria YC6889, YC6894, YC6896, YC6897, YC6901 and YC6810, which belonged to Firmicutes, Actinomycetes and $\gamma$-Proteobacteria $(\mathrm{n}=7 ; 30.4 \%)$. $\beta$-1,3-glucanase activity was detected in many antagonistic endophytic bacterial strains $(n=11$; $47.8 \%$ ) from different groups, but no single group from all six major taxonomic groups of antagonistic endophytic bacteria showed dominance. Not a single antagonistic endophytic bacterial strain of a certain genus or species showed all of the tested enzymatic activities.

Characterization of plant growth promotion traits of antagonistic endophytic bacteria. The putative new antagonistic endophytic strains (YC6887 and YC6898) from the novel genera were selected for further characterization of their plant growth promotion traits such as phosphate solubilization, IAA and siderophore production and nitrate reduction. Two selected endophytic bacterial strains isolated from coastal dune plants $R$. rugosa and $S$. maritima, respectively, belonged to the class $\alpha$-Proteobacteria. The traits related to plant growth promotion of the bacteria are listed in Table 3. Of the tested growth promotion characteristics, both strains solubilized tricalcium phosphate and produced IAA. The strains YC6887 and YC6898 displayed the development of a clear zone around colonies as an indication of phosphate solubilization activity. Siderophore production was also determined for both strains. Only strain YC6898 produced siderophore. Nitrate reduction activity was observed only in strain YC6887 (Table 3). That strain showed $A$. thaliana root and shoot growth promotion activities compared to the control and strain YC6898 after four weeks of cultivation.

\section{Discussion}

Bacterial diversity and information on the function of individual plant community members can be obtained by culture-dependent and culture-independent analyses (Araujo et al., 2002). A culture-dependent approach was applied in the present study to investigate the diversity and isolate antagonistic endophytic bacteria from tidal flat plants against two important plant pathogens: P. capsici and Py. ultimum. The screening of 256 endophytic bacteria on the basis of their antagonistic potential against oomycetes and subsequent identification on partial 16S rRNA gene sequence resulted in diversity of different groups of bacteria comprising 10 different genera. Endophytic bacterial colonization appeared to be abundant in the root tissues of the halophytes, which may be reflection of a primary site for endophytes to gain entry into plants. Antibiotic production may be one of the mechanisms used by these endophytic bacteria to dominate the host by deterring other potential colonizers (Coombs et al., 2004). The preference of endophytic bacteria for root tissue reflects the presence of high levels of nutrients in the rhizosphere and the capability of the nutrients to support higher bacterial growth and metabolism in roots compared with other tissues (Berg and Hallmann, 2006; Kobayashi and Palumbo, 2000).

Presently, all six tidal flat plants harbored a large fraction $(n=23,9.0 \%)$ of endophytic bacteria that were antagonists against oomycetes. In contrast to our study, a previous study documented a much higher number (27.5-62.6\%) of bacterial antagonists to the common plant pathogenic fungi Rhizoctonia solani, Py. ultimum, Fusarium oxysporum, and Botrytis cinerea in eight coastal dune plants (Kim et al., 2010; Shin et al., 2007). This may be because we used only oomycetes as target organisms, while in the previous study the initial screening included many target pathogens. We examined the distribution of antagonistic endophytic bacteria in the root tissues from commonly growing halophytes in our area for two reasons. Firstly, very few studies have been done on the isolation of antagonistic bacteria to plant oomycete pathogens, which may increase the possibility to discover bacteria with novel biocontrol properties. Secondly, antagonistic endophytic bacteria residing in the halophytes, especially in tidal flat habitats where these plants are 
partially or fully submerged in seawater, may have adapted well to a highly moist environment, which provides a good source for isolation of antagonistic bacteria against oomycetes plant pathogens.

The neighbor-joining phylogenetic method yielded consensus tree topology that grouped all 16S rRNA gene sequences obtained from endophytic antagonists into four different groups: Firmicutes (Bacillus, Staphylococcus and Paenibacillus), $\alpha$-Proteobacteria (Martelella and Hoeflea), $\gamma$-Proteobacteria (Pseudomonas and Stenotrophomonas) and Actinomycetes (Micrococcus, Microbacterium and Mycobacterium) (Figs. 1 and 2). Some genera were represented by several species, and some endophytes proved to be different strains of the same species. Our results indicated that among the overall phylogenetic distribution of bacterial communities of six tidal flat plants, Firmicutes $(47.8 \%)$ was the most prevalent endophytic bacterial group based on 16S rRNA gene sequence analysis (Tables 1 and 2). Bacteria belonging to this group are easy to cultivate and frequently found as endophytes. This is consistent with most previous studies, where the antagonistic properties against oomycetes were reported to be common within different strains of genus Bacillus that are endophytes of several plant species (Berg and Hallmann, 2006; Misaghi and Donndelinger, 1990). These are known to generate spores under adverse conditions, which might help to ensure their survival under environmental stresses and to be used to control different plant diseases caused by oomycetes (Handelsman et al., 1990). A wide variety of antibacterial, antifungal antibiotics, enzymes and surfactants are produced by different species of Bacillus, which promote plant growth and induce systemic resistance in plants (Kloepper et al., 2004; Leclère et al., 2005; Yoshida et al., 2001). The other representative of Firmicutes and Staphylococcus species are also already known to produce antifungal substances (Barbieri et al., 2005).

Seventeen percent of the total strains were identified as Actinomycetes and these were found only in two plant species, $S$. maritima and $V$. rotundifolia. Actinomycetes are effective antagonists of plant fungal pathogens and are common antibiotic producers (Coombs et al., 2004; Jung et al., 2002). These are considered as metabolically and morphologically diverse as compared with sessile bacteria by producing mycelia and spore structures resulting in plant colonization and inducing defense pathway (Conn et al., 2008). In this study, $\gamma$-Protobacteria including mainly Pseudomonas and Stenotrophomonas species were found to have antagonistic activity against oomycetes plant pathogens. Pseudomonas species, which are very common in seawater, sponges and plants, are used as biocontrol agents because of their production of various metabolites (Keel et al., 1989; Kobayashi et al., 1998; McSpadden-Gardener et al., 2005; Ó Sullivan and Ó Gara, 1992; Romanenko et al., 2005). The potential use of Stenotrophomonas spp. as a biocontrol agent of fungal pathogens has been also explored (Zhang and Yuen, 1999). Most of the antagonistic endophytic bacteria identified in this study, Pseudomonas, Stenotrophomonas, Bacillus, Microbacterium and Paenibacillus, are already defined for the antagonism and plant growth promotion as biocontrol agent (Berg and Hallmann, 2006; Brooks et al., 1994; Rosenblueth and MartínezRomero, 2006; Singh et al., 1999).

In the present study, $9.0 \%$ of the antagonistic endophytic bacteria were related to $\alpha$-Proteobacteria, encompassing mainly endophytic strains closely related to the type strain of the genera Martelella and Hoeflea. The newly established genus Martelella contains only one species Martelella mediterranea isolated from lake water and a novel gene encoding an endoglucanase (Cel5D) was cloned recently from this species (Dong et al., 2010). The strain YC6887 closely related to $M$. mediterranea was isolated from the halophyte, which indicates that this group of bacteria may be widely distributed in a range of aquatic environments. Hoeflea is one of the most abundant genus found in marine environment and widely distributed in dinoflagellate (Palacios et al., 2006). Several new species of $\alpha$-Proteobacteria isolated from terrestrial as well as various marine sources have been reported to produce antibiotics (Thorsten et al., 2004; Wagner-Dobler et al., 2004). Members of this class are nitrogen-fixing organisms that live in symbiosis with plants and produce bioactive compounds and secondary metabolites for chemical signaling and defense in host-microbe interactions (Gage, 2004; Long and Azam, 2001; Mohamed et al., 2008).

Some endophytic bacteria with antagonistic activity isolated from the six coastal dune plants were able to degrade biopolymers such as cellulose and $\beta$-1,3-glucan, which are major cell wall components of oomycetes. Although significant differences were found in the production of these hydrolytic enzymes that are important in antagonism, no significant correlation was observed between the production of lytic enzymes and the range of antagonism against $P y$. ultimum and $P$. capsici. However, most endophytic antagonistic bacteria in the class $\alpha$-Proteobacteria, $\gamma$-Proteobacteria and Firmicutes in this study exhibited cellulase activity, which indicates their potential in the antagonism and inter- or intracellular colonization of roots (Al-Mallah et al., 1987; Compant et al., 2005). In addition to antibiotic and hydrolytic enzyme production, strain YC6887 also showed growth promotion of $A$. thaliana. Growth promotion of plants is another key factor to be considered in the development of endophytic bacteria as biocontrol agents, since the selected bacteria may indirectly affect the pathogenicity of fungal pathogens by simultane- 
ous induction of systemic resistance of host plants (Kloepper and Ryu, 2006; Manjula et al., 2002). Presently, strain YC6887 was shown to solubilize phosphate and produce IAA, which may be instrumental in mediating plant growth promotion. Phosphorus is one of the most important plant nutrients. A large portion of inorganic phosphates applied to soil as fertilizer is rapidly immobilized after application and becomes unavailable to plants. Many endophytic bacteria possess the capacity to solubilize immobilized mineral phosphates, suggesting that during initial colonization, the endophytic bacteria could enhance phosphate availability to the host plant (Berg and Hallmann, 2006; Rodriguez and Fraga, 1999). Siderophore production of strain YC6898 may be important for outcompeting pathogens as the bacterial siderophores are utilized by plants as an iron source and they compete with fungal pathogens for the iron supply (Ó Sullivan and Ó Gara, 1992; Scher and Baker, 1982; Wang et al., 1993). Strain YC6887, which was originally isolated from $R$. rugosa, a tidal flat plant, can colonize the roots of $A$. thaliana and promote its growth. Thus, the potential exists to introduce this non-indigenous endophytic bacterium to various host plants as a biocontrol agent of plant diseases, since many endophytic bacteria can establish themselves in plants other than their original hosts, indicating a lack of host specificity (Rosenblueth and Martínez-Romero, 2006). Further analysis of the new strains described in this study is ongoing to understand the mechanisms involved in suppression of oomycetes plant pathogen and plant growth promotion.

Bacteria commonly studied and deployed for control of oomycete plant pathogens include species of Bacillus, Pseudomonas and Streptomyces, while the diversity of biocontrol traits in most bacteria other than these remains virtually untapped. The exploitation of biocontrol agents in the field is limited by inefficacy of those bacteria under adverse environmental conditions such as high moisture (McCormack et al., 1995). Our recovery of antagonistic endophytic bacteria against oomycetes from tidal flat plants suggests that these plants may harbor diverse bacteria to adapt and protect themselves under adverse conditions. The roots of tidal flat plants, therefore, represent an ecological niche that harbors a largely uncharacterized bacterial variety. Adaptation to adverse conditions may include the production of specic novel secondary metabolites that are important in bacterial survival, either in a free-living state or in association with host plants, conferring an advantage over other bacteria (Jensen and Fenical, 1996; Nathan et al., 2004).

In conclusion, this study demonstrates the taxonomic diversity and occurrence of antagonistic endophytic bacteria with different physiological and biochemical capabilities, which may provide a basis for the isolation of new potent biocontrol agents of oomycete plant pathogens. Furthermore, it appears that tidal flat plants can be an important source of endophytic bacteria that induce plant growth promotion and defense against plant pathogens. Future studies will focus on $\alpha$-Proteobacteria strain YC6887 concerning development as a commercial biocontrol agent and structure determination of antibiotic compounds.

\section{Acknowledgments}

This work was supported by a grant of research and business development, the Ministry of Food, Agriculture, Forestry and Fisheries (\#808015-3) in cooperation with JGreen Inc. The scholarship for F. Bibi, M. Yasir and G.C. Song was supported by a grant from Brain Korea (BK) 21 project in 2008-2010, partially by a grant from Environmental Biotechnology National Core Research Center in 2008, the Ministry of Education, Science and Technology, Korea.

\section{References}

Agrios, G. N. 2005. Disease caused by oomycetes. Pages 409-428 in: Plant Pathology. $5^{\text {th }}$ ed. Academic Press, New York.

Al-Mallah, M. K., Davey, M. R. and Cooking, E. C. 1987. Enzymatic treatment of clover root hairs removes a barrier to Rhizobium host specificity. Biotechnology 5:1319-1322.

Araujo, W. L., Marcon, J., Maccheroni, W, Jr., Van Elsas, J. D., Van Vuurde, J. W. L. and Azevedo, J. L. 2002. Diversity of endophytic bacterial populations and their interaction with Xylella fastidiosa in citrus plants. Appl. Environ. Microbiol. 68:4906-4914.

Barbieri, E., Gioacchini, A. M., Zambonelli, A., Bertini, L. and Stocchi, V. 2005. Determination of microbial volatile organic compounds from Staphylococcus pasteuri against Tuber borchii using solid-phase microextraction and gas chromatography/ion trap mass spectrometry. Rapid Commun. Mass Spectrom. 19:3411-3415.

Berg, G. and Hallmann, J. 2006. Control of plant pathogenic fungi with bacterial endophytes. Pages 53-69 in: Microbial root endophytes. B. Schulz, C. Boyle, and T. N. Sieber, eds. Springer-Verlag, Berlin.

Brooks, D. S., Gonzalez, C. F., Appel, D. N. and Filer, T. H. 1994. Evaluation of endophytic bacteria as potential biological control agents for oak wilt. Biol. Control 4:373-381.

Chert, C., Bauske, E. M., Musson, G., Rodriguez-Kabana, R. and Kloepper, J. W. 1995. Biological control of Fusarium wilt of cotton by use of endophytic bacteria. Biol. Control 5:10-16.

Chung, B. S., Aslam, Z., Kim, S. W., Kim, G. G., Kang, H. S., Ahn, J. W. and Chung, Y. R. 2008. A bacterial endophyte, Pseudomonas brassicacearum YC5480 isolated from the root of Artemisia sp. producing antifungal and phytotoxic compounds. Plant Pathol. J. 24:461-468.

Compant, S., Reiter, B., Sessitsch, A., Nowak, J., Clement, C. and Ait Barka, E. 2005. Endophytic colonization of Vitis vinifera 
L. by plant growth-promoting bacterium Burkholderia sp. strain PsJN. Appl. Environ. Microbiol. 71:1685-1693.

Conn, V. M., Walker, A. R. and Franco, C. M. M. 2008. Endophytic actinobacteria induce defense pathways in Arabidopsis thaliana. Mol. Plant-Microbe Interact. 21:208-218.

Coombs, J. T. and Franco, C. M. M. 2003. Isolation and identification of actinobacteria isolated from surface-sterilized wheat roots. Appl. Environ. Microbiol. 69:5303-5308.

Coombs, J. T., Michelsen, P. P. and Franco, C. M. M. 2004. Evaluation of endophytic actinobacteria as antagonists of Gaeumannomyces graminis var. tritici in wheat. Biol. Control 29:359-366.

Chung, E. J., Park, J. H., Park, T. S., Ahn, J.-W. and Chung, Y. R. 2010. Production of a phytotoxic compound, 3-phenyl propionic acid by a bacterial endophyte, Arthrobacter humicola YC6002 isolated from the root of Zoysia japonica. Plant Pathol. J. 26:245-252.

Dalton, D. A., Kramer, S., Azios, N., Fusaro, S., Cahill, E. and Kennedy, C. 2004. Endophytic nitrogen fixation in dune grasses (Ammophila arenaria and Elymus mollis) from Oregon. FEMS Microbiol. Ecol. 49:469-479.

Davidson, S. K., Allen, S. W., Lim, G. E., Anderson, C. M. and Haygood, M. G. 2001. Evidence for the biosynthesis of Bryostatins by the bacterial symbiont "Candidatus Endobugula sertula" of the Bryozoan Bugula neritina. Appl. Environ. Microbiol. 67:4531-4537.

Domenech, J., Ramos, S. B., Probanza, A., Lucas, G. J. A. and Gutierrez, M. F. J. 2007. Elicitation of systemic resistance and growth promotion of Arabidopsis thaliana by PGPRs from Nicotiana glauca: a study of the putative induction pathway. Plant Soil. 290:43-50.

Dong, J., Hong, Y., Shao, Z. and Liu, Z. 2010. Molecular cloning, purification, and characterization of a novel, acidic, $\mathrm{pH}$-stable endoglucanase from Martelella mediterranea. J. Microbiol. 48:393-398.

Gage, D. J. 2004. Infection and invasion of roots by symbiotic, nitrogen-fixing rhizobia during nodulation of temperate legumes. Microbiol. Mol. Biol. Rev. 68:280-300.

Gordon, S. A. and Weber, R. P. 1951. Colorimetric estimation of indoleacetic acid production. Plant Physiol. 26:192-195.

Hallmann, J. and Berg, G. 2006. Spectrum and population dynamics of bacterial root endophytes. Pages 15-31 in: Microbial Root Endophytes. B. Schulz, C. Boyle, and T. N. Sieber, eds. Springer-Verlag, Berlin.

Handelsman, J., Raffel, S., Mester, E. H., Wunderlich, L. and Grau, C. R. 1990. Biological control of damping-off of alfalfa seedlings with Bacillus cereus UW85. Appl. Environ. Microbiol. 56:713-718.

Hendricks, C. W., Doyle, J. D., and Hugley, B. 1995. A new solid medium for enumerating cellulose-utilizing bacteria in soil. Appl. Environ. Microbiol. 61:2016-2019.

Hong, T. Y. and Meng, M. 2003. Biochemical characterization and antifungal activity of an endo-1,3- $\beta$-glucanase of Paenibacillus sp. isolated from garden soil. Appl. Microbiol. Biotechnol. 61:472-478.

Jensen, P. R. and Fenical, W. 1996. Marine bacterial diversity as a resource for novel microbial products. J. Ind. Microbiol. Biotechnol. 17:346-351.

Jensen, P. and Fenical, W. 2000. Marine microorganisms and drug discovery: current status and future potential. Pages 6-79 in: Drugs from the sea. N. Fusetani, ed., Karger, Basel, Switzerland.

Jung, W. J. H., Kitamura, E., Myouga, H. and Kamei, Y. 2002. An antifungal protein from the marine bacterium Streptomyces sp. strain AP77 is specific for Pythium porphyrae, a causative agent of red rot disease in Porphyra spp. Appl. Environ. Microbiol. 68:2666-2675.

Keel, C., Voisard, C., Berling, C. H., Kahr, G. and Défago, G. 1989. Iron sufficiency, a prerequisite for the suppression of tobacco black root rot by Pseudomonas fluorescens strain CHA0 under gnotobiotic conditions. Phytopathology 79:584589.

Kim, S. G., Jang, Y., Kim, H. Y., Koh, Y. J., and Kim, Y. H. 2010. Comparison of microbial fungicides in antagonistic activities related to the biological control of phytophthora blight in chili pepper caused by Phytophthora capsici. Plant Pathol. J. 26:340-345.

Kloepper, J. W., Ryu, C.-M. and Zhang, S. 2004. Induced systemic resistance and promotion of plant growth by Bacillus spp. Phytopathology 94:1259-1266.

Kloepper, J. W. and Ryu, C.-M. 2006. Bacterial endophytes as elicitors of induced systemic resistance. Pages 33-52 in: Microbial root endophytes. B. Schulz, C. Boyle, and T. N. Sieber, eds. Springer-Verlag, Berlin.

Kobayashi, D. Y. and Palumbo, J. D. 2000. Bacterial endophytes and their effects on plants and uses in agriculture. Pages 199233 in: Microbial Endophyte. C.W. James, and J. F. White, eds. Marcel Dekker Inc, New York.

Kobayashi, S., Hodaka, S., Kawamura, Y., Ozaki, M. and Hayase, Y. 1998. Micacocidin A, B and C, novel antimycoplasma agents from Pseudomonas sp. J. Antbiotics 51:323-332.

Leclère, V., Bechet, M., Adam, A., Guez, J. S., Wathelet, B., Ongena, M., Thonart, P., Gancel, F., Chollet-Imbert, M. and Jacques, P. 2005. Mycosubtilin overproduction by Bacillus subtilis BBG100 enhances the organism's antagonistic and biocontrol activities. Appl. Environ. Microbiol. 71:4577-4584.

Lemos, M. L., Toranzo, A. E. and Barja, J. L. 1985. Antibiotic activity of epiphytic bacteria isolated from intertidal seaweeds. Microb. Ecol. 11:149-163.

Long, R. A. and Azam, F. 2001. Antagonistic interactions among marine pelagic bacteria. Appl. Environ. Microbiol. 67:49754983.

Maidak, B. L., Olsen, G. J., Larsen, N., Overbeek, R., McCaughey, M. J. and Woese, C. R. 1996. The ribosomal database project (RDP). Nucleic Acids Res. 24:82-85.

Manjula, K., Singh, S. D. and Kishore, K. G. 2002. Role of endophytic bacteria in biological control of plant diseases. Ann. Rev. Plant Pathol. 1:231-252.

McCormack, P., Wildman, H. and Jeffries, O. 1995. The influence of moisture on the suppression of Pseudomonas syringae by Aureobasidium pullulans on an artificial leaf surface. FEMS Microbiol. Ecol. 16:159-166. 
McSpadden-Gardener, B. B., Gutierrez, L. J., Joshi, R., Edema, R. and Lutton, E. 2005. Distribution and biocontrol potential of phlD $(+)$ pseudomonads in corn and soybean fields. Phytopathology 95:715-724.

Misaghi, I. J. and Donndelinger, C. R. 1990. Endophytic bacteria in symptom-free cotton plants. Phytopathology 80:808-811.

Mohamed, M., Cicirelli, E. M., Kan, J., Chen, F., Fuqua, C. and Hill, R. T. 2008. Diversity and quorum-sensing signal production of Proteobacteria associated with marine sponges Nagl. Environ Microbiol. 10:75-86.

Nathan, A. M., Jessica, M. K., Valerie, B., Martin, D. and David, H. S. 2004. Isolation and characterization of novel marinederived actinomycete taxa rich in bioactive metabolites. Appl. Environ. Microbiol. 70:7520-7529.

Nautiyal, C. S. 1999. An efficient microbiological growth medium for screening phosphate solubilizing microorganisms. FEMS Microbiol. Lett. 170:265-270.

Ó Sullivan, D. G. and Ó Gara, F. 1992. Traits of fluorescent Pseudomonas spp. involved in suppression of plant root pathogens. Microbiol. Rev. 56:662-676.

Palacios, L., Arahal, D., Reguera, B. and Marin, I. 2006. Hoeflea alexandrii sp. nov., isolated from the toxic dinoflagellate Alexandrium minutum AL1V. Int. J. Syst. Evol. Microbiol. 56: 1991-1995.

Perez-Miranda, S., Cabirol, N., George-Téllez, R., ZamudioRivera, L. S. and Fernandez, F. J. 2007. O-CAS, a fast and universal method for siderophore detection. J. Microbiol. Meth. 70:127-131.

Rodriguez, H. and Fraga, R. 1999. Phosphate solubilizing bacteria and their role in plant growth promotion. Biotechnol. Adv. 17: 319-339.

Romanenko, L. A., Uchino, M., Falsen, E., Frolova, G. M., Zhukova, N. V. and Mikhailov, V. V. 2005. Pseudomonas pachasterellae sp. nov., isolated from a marine sponge. Int. J. Syst. Evol. Microbiol. 55:919-924.

Rosenblueth, M. and Martínez-Romero, E. 2006. Bacterial endophytes and their interactions with hosts. Mol. Plant-Microbe Interact. 19:827-837.

Ryu, C.-M., Farag, M. A., Hu, C. H., Reddy, M. S., Wei, H. X., Pare, P. W. and Kloepper, J. W. 2003. Bacterial volatiles promote growth in Arabidopsis. Proc. Natl. Acad. Sci. USA 100:4927-4932.

Scher, F. M. and Baker, R. 1982. Effect of Pseudomonas putida and a synthetic iron chelator on induction of soil suppressiveness to Fusarium wilt pathogens. Phytopathology 72:15671573.

Schulz, B. and Boyle, C. 2006. What are endophytes? Pages 1-13 in: Microbial Root Endophytes. B. Schulz, C. Boyle, and T. N. Sieber, eds. Springer-Verlag, Berlin.
Singh, P. P., Shin, Y. C., Park, C. S. and Chung, Y. R. 1999. Biological controls of Fusarium wilt of cucumber by chitinolytic bacteria. Phytopathology 92:92-99.

Sgroy, V., Cassán, F., Masciarelli, O., Florencia Del Papa, M., Lagares, A. and Luna, V. (2009). Isolation and characterization of endophytic plant growth-promoting (PGPB) or stress homeostasis-regulating (PSHB) bacteria associated to the halophyte Prosopis strombulifera. Appl. Microbiol. Biotechnol. 85:371-381.

Shin, D, S., Park, M. S., Jung, S., Lee, M. S., Lee, K. H., Bae, K, S. and Kim, S, B. 2007. Plant growth-promoting potential of endophytic bacteria isolated from roots of coastal sand dune plants. J. Microbiol. Biotechnol. 17:1361-1368.

Smibert, R. and Krieg, N. R. 1994. Phenotypic characterization. Pages 607-654 in: Methods for General and Molecular Bacteriology, P. Gerhardt, R. G. E. Murray, W. A. Wood., and N. R. Krieg, eds. American Society for Microbiology, Washington, DC.

Strobel, G. 2003. Endophytes as sources of bioactive products. Microbes. Infect. 5:53-544.

Tamura, K., Dudley, J., Nei, M. and Kumar, S. 2007. MEGA4: Molecular evolutionary genetics analysis (MEGA) software version 4.0. Mol. Biol. Evol. 24:1596-1599.

Thompson, J. D., Gibson, T. J., Plewniak, F., Jeanmougin, F. and Higgins, D. G. 1997. The Clustal X Windows interface: Flexible strategies for multiple sequence alignment aided by quality analysis tools. Nucleic Acids. Res. 25:4876-4882.

Thorsten, B., Gabriela, B., Thorsten, H., Lanfang, L., Andrea, S. and Meinhard, S. 2004. Antibiotic production by a Roseobacter clade-affiliated species from the German Wadden Sea and its antagonistic effects on indigenous isolates. Appl. Environ. Microbiol. 70:2560-2565.

Wagner-Dobler, I., Rheims, H., Felske, A., El-Ghezal, A., FladeSchröder, D., Laatsch, H., Lang, S., Pukall, R. and Tindall, B. J. 2004. Oceanibulbus indolifex gen. nov., sp. nov., a North Sea á-proteobacterium that produces bioactive metabolites. Int. J. Syst. Evol. Microbiol. 54:1177-1184.

Wang, Y., Brown, H. N., Crowley, D. E. and Szaniszlo, P. J. 1993. Evidence for direct utilization of a siderophore, ferrioxamine $\mathrm{B}$, in axenically grown cucumber. Plant Cell Environ. 16: 579-585.

Yoshida, S., Hiradate, S., Tsukamoto, T., Hatakeda, K. and Shirata, A. 2001. Antimicrobial activity of culture filtrate of Bacillus amyloliquefaciens RC-2 isolated from mulberry leaves. Phytopathology 91:181-187.

Zhang, Z. and Yuen, G. Y. 1999. Biological control of Bipolaris sorokiniana on tall fescue by Stenotrophomonas maltophilia C3. Phytopathology 89:817-822. 